\title{
Subaltern Experimental Writing: Dalit Literature in Dialogue with the World
}

Nicole Thiara

\begin{abstract}
This essay analyses the experimental features of three contemporary novels produced by Dalits in relation to the novels' approach to caste and national and international audiences. Bama's Sangati (1994), Sharankumar Limbale's Hindu (2003), and G. Kalyana Rao's Untouchable Spring (2000) create fragmented, innovative, and complex narrative structures that are experimental both in their attempts to reflect oral narrative structures that validate the unique communal legacy of Dalit culture and their production of radically new narrative strategies that evoke a world free from caste discrimination. The essay also explores the novels' complex positioning of multiple readers and the distinctive features of their English translations. The three translations re-code the texts for international consumption but simultaneously try to keep the novels somewhat "strange"; the translations, which attempt to replicate the novels' innovative features, are also emphatically experimental.
\end{abstract}

Keywords: Dalit, subaltern, experimental writing, Bama, Sharankumar Limbale, G. Kalyana Rao

The emergence of literature produced by Dalits in India over the last thirty to forty years is perhaps the most significant contemporary phenomenon of subaltern writing. ${ }^{1}$ Sharankumar Limbale, a Dalit writer and critic, defines Dalit literature as "writing about Dalits by Dalit writers with a Dalit consciousness" (Towards an Aesthetic 19). ${ }^{2}$ Dalits (formerly referred to as Untouchables) are positioned at the bottom of the caste hierarchy and have long been one of India's most silenced com- 
munities. In independent India, the fight against caste discrimination is closely tied to the development of Dalit literature that seeks to give voice to Dalits and their unique experience of oppression based on concepts of pollution and untouchability: "Dalit literature is born from the womb of this untouchability. This is its uniqueness" (Limbale, Towards an Aesthetic 29). This essay analyses the experimental features of three Dalit novels in relation to how they address Dalit, national, and global audiences. It discusses the English translations of Bama's novel Sangati (published in Tamil in 1994 and translated by Lakshmi Holmström in 2005), G. Kalyana Rao's novel Untouchable Spring (published in Telugu as Antarani Vasantam in 2000 and translated by Alladi Uma and M. Sridhar in 2010), and Limbale's novel Hindu (published in Marathi in 2003 and translated by Arun Prabha Mukherjee in 2010). In contrast to most contemporary criticism of Dalit writing, which often neglects fiction in favour of autobiographies, I argue for the comparative study of the formal innovations of Dalit fiction and approach these three texts as a case study in experimentation. ${ }^{3}$ Experimental writing, with its "qualities of shock and affront," violates the conventions of mainstream literature and is "one of the engines of literary change and renewal" (Bray, Gibbons, and McHale 1-2). I understand literary experimentation in this essay as the creation of innovative and unconventional narrative strategies and features in the contemporary Dalit novel that: are rooted in local Indian realities, subaltern vernacular traditions, and histories of anti-caste resistance; aim to challenge upper-caste and bourgeois aesthetics; and envisage a world free from caste discrimination. Experimentation is also an effect of Dalit literature's engagement of multiple audiences to communicate radical politics and initiate dialogues across barriers of caste, class, and national boundaries. Finally, I analyse how the translations of the texts are marketed to an Englishspeaking, potentially global audience and how such translations negotiate and contribute to the texts' experimental aesthetics.

Comparing these three novels is productive because they are prominent examples of Dalit literature produced by three of the most well known Dalit writers. Limbale is a Dalit writer-activist from Maharashtra whose collection of critical essays Towards an Aesthetic of Dalit Literature: 
History, Controversies and Considerations (2004) was one of the first volumes of Dalit literary criticism available in English. ${ }^{4}$ Limbale was associated with the Dalit Panthers, a prominent Dalit literary movement in Maharashtra in the 1970s, which inaugurated a new phase of Dalit literature and perceived literature as a key weapon in the fight against untouchability and the caste system (Dangle xxxviii-xli). 5 This new wave of Dalit literature flourished in the state, which was the home of prominent Dalit leader Bhimrao Ramji Ambedkar (1891-1956). The Dalit literature produced there (mainly in Marathi) is heavily influenced by his ideas, strategies, and writings, although the Dalit Panthers also drew on Marxism and the example of the Black Panthers in the United States (Omvedt). ${ }^{6}$ Ambedkar remains the crucial reference point for Dalit writers from that region (Limbale, Towards an Aesthetic 40-51). Other regional traditions of Dalit writing developed from the 1970s on, predominantly in South India where Tamil Nadu produced a rich tradition of Dalit literature (Ravikumar). Bama is now one of the most widely read and studied Tamil writers and the most influential female Dalit author. Her novels have redefined the literary landscape in Tamil Nadu, and her autobiography Karukku (1992) and her novels Sangati and Vanmam (2002) have been translated into English. Her texts focus on the Dalit caste of the Paraiyars, one of the largest "Untouchable" castes in Tamil Nadu. Kalyana Rao is from Andhra Pradesh, South India. Antarani Vasantam (Untouchable Spring) was the "first Dalit historical novel in Telugu" (Reddy 86). It is one of the most acclaimed and widely translated novels in Dalit literature and focuses on the Malas and Madigas, the largest "Untouchable" castes in Andhra Pradesh.

The three novels considered in this essay emerged from three regions in India with varied histories of anti-caste movements and the development of Dalit literature. Consequently, the texts differ significantly in subject matter and content, which are related to their different regional settings and politics. Bama's novel represents a Dalit village community from the perspective of a female narrator; Limbale's text depicts casteist politics and violence in a village outside Mumbai and centres on the murder of a Dalit activist; and Kalyana Rao's novel narrates the history of a Dalit family and community over several generations. However, all 
three are linked by commonalities in their experiments with form and language. In particular, they employ fragmented, innovative, and complex narrative structures that are experimental both in their reflection of oral narrative structures that validate the unique communal legacy of Dalit culture and how they seek to produce narrative strategies that are radically new in order to evoke a world beyond caste.

Dalit texts are generally analysed as part of a regional literary landscape and in the context of a specific vernacular literature. However, I argue for a transregional comparative approach to analysing Dalit texts in translation, which is both instructive and necessary for an exploration of the formal features shared by Dalit fiction across the barriers of regional languages. Furthermore, I suggest that more studies are needed to explore the specific challenges of translating Dalit vernacular texts into English and the processes of dissemination that determine how Dalits engage in a dialogue with the world in English. To this end, this essay analyses the texts' representation of caste and shifting narrative perspectives and multiple protagonists that produce new ways of writing (and interrogating) community. It explores the novels' complex positioning of multiple readers and analyses how three distinct sets of readers-a Dalit readership, a non-Dalit subcontinental readership, and a global audience-are inscribed in the texts. Finally, the essay discusses how the three English translations re-code the texts for global consumption but simultaneously try to keep the novels somewhat "strange." I conclude that the translations are emphatically experimental in their attempt to replicate the Dalit novels' innovative features.

\section{Experiments in Dalit Fiction: Structure, Narrative, Style}

The experimental and innovative features of the three novels are not unique to these texts; on the contrary, experimentation with language, narrative voice, form, and genre are defining features of Dalit literature. Toral Jatin Gajarawala argues that " $[t]$ here is no doubt that Dalit literature is infused with a radical newness and is quite literally unlike anything lettered before" (198). Dalit writing is innovative by its very nature because it seeks to be revolutionary in both form and content in order to subvert the literary and aesthetic conventions of the upper 
castes and challenge mainstream readers' received assumptions about art and aesthetic value more broadly.

However, Dalit criticism does not often celebrate Dalit literature's experimental quality. Instead, Dalit literary texts are frequently approached as outpourings of social pain and anger whose authenticity is manifested in a certain rawness and "artlessness" (Limbale, Towards an Aesthetic 108). Such scholarship suggests that Dalit literature's primary aim is Dalit empowerment. Aesthetic concerns are secondary at best and should support the works' political aims rather than be foregrounded for their own sake. Limbale's remarks are typical of this view. He defends criticism of Dalit literature, emphasising its sociological function and purpose rather than its literary characteristics. Adopting the role of spokesperson for Dalit authors, Limbale claims that "Dalit writers believe that their literature should be analyzed from a sociological perspective focused on social values [rather] than on beauty. An exclusively aesthetic consideration of Dalit literature will disregard the Dalit writers' fundamental role, and hence is not acceptable to Dalit writers" (19). Consequently, Laura R. Brueck argues that "Dalit literary theory itself is too often dismissive, perhaps wilfully so, of the diversity and complexity of the literary strategies employed by Dalit authors . . . to protect the boundaries of Dalit literature from dissimulation into multiple, individual authorial approaches that, when differentiated and divided, lose their unified political impact" (7). Dalit criticism's underestimation of Dalit literature's aesthetic ambition is also partly a reaction to the dismissal of Dalit literature as "good" literature by many of India's mainstream (and therefore usually upper-caste) critics (Dangle xlviii; Limbale, Towards an Aesthetic 34). Ironically, the perception that Dalit literature is not "polished" gives Dalit writers the creative autonomy to develop experimental features. In their initial print runs, Dalit texts are often published by small (rather than commercial) presses that seek to give marginalised voices a chance to be heard (Satyanarayana and Tharu, Introduction, No Alphabet 25-27). Therefore, many Dalit literary texts do not need to conform to the genre conventions and narrow concerns of mainstream publishing. This essay follows the more recent trend of critical studies, exemplified by Gajarawala and Brueck, that focuses on the literary 
and aesthetic features of Dalit literature in order to complement-not diminish - analysis of Dalit literature's political potential. That is, I read the experimental form of these novels as explicitly linked to their political content and seeking to create an aesthetics of empowerment.

Experimental features shared by Bama's, Limbale's, and Kalyana Rao's novels include the fragmentation of narrative structure, use of multiple protagonists, and shifting narrative perspectives that imagine communal forms of representation. All three novels incorporate oral storytelling strategies and motifs that draw on specific community oral traditions and culture. For instance, Bama's novel Sangati relates the story of Christian Dalit women in their segregated part of an unnamed village in Tamil Nadu. On the surface, the novel is organized around first-person narration, yet the reader is initially denied the sort of clearly defined picture of richly crafted interiority that one might expect of bourgeois psychological realism. The text is less concerned with the narrator's individual identity and more invested in capturing and narrating other women's stories, particularly those of the narrator's grandmother. This community of women is represented as intimate and close-knit: everyone knows everything about everybody else. The cast of significant female characters is so large, with each woman's story leaking into the next, that the reader is encouraged to perceive them as interdependent rather than sharply individuated characters. They are invested with distinctive traits, but no one woman's story is fully disclosed on its own. Instead, the narrative provides a portrait of the Dalit neighbourhood as a whole from the collective perspective of its female residents. Only the grandmother, the central figure, is fleshed out in greater detail: Paatti is respected in the Dalit community and functions as chronicler of its history and traditions. Her stories and presence act as a kind of glue that provides the text with narrative coherence; however, her storytelling does not produce a linear sense of chronology. Events unfold in a way that feels plotless and instantaneous and new storylines are often introduced abruptly, as in the following passage:

The way Paatti shouted, all the people there dropped whatever they were doing and came running up to her. As soon as seven 
or eight people had gathered around her, Paatti sat down at leisure and began to speak in detail about Manacchi [a girl who was possessed]. I was drinking my kanji at the time, so I lifted up my bowl, gulped it down, washed my hands haphazardly, and ran up to Paatti to hear her story. (Bama, Sangati 45)

Sangati both follows and subverts the genre of the Bildungsroman. The first-person narrator matures and develops over the course of the narrative but remains in the background of the action, witnessing and recording the experiences of the women surrounding her. The text is a kind of Bildungsroman by stealth in which the narrator learns by listening to stories, questioning the caste and patriarchal practices that thwart the women and in the process becoming a staunch Dalit feminist. The novel refuses the narrative of individualist development in favour of the Bildungsroman reimagined as a collective form in which interrelation and interdependence, rather than autonomy, are crucial to the protagonist's personal development.

Sangati depicts a vibrant oral folk culture that is a mainly female practice. The women manage their difficult lives, and give those lives dignity and coherence, by weaving songs and stories into their daily routines. The narrative structure's dialogic fluidity mirrors colloquial conversations in that one topic leads to the next by means of association and digression. The individual anecdotes are loosely strung together throughout the text, and while every chapter focuses on a specific subject, such as the daily routines of domestic chores or women being possessed by spirits, the chapters seep into one another. The topic of each successive chapter is often suggested by a comment or incident in the previous one. The first chapter, for example, ends with the statement that "Mariamma came of age" (14), and the following chapter picks up on this seamlessly by providing a detailed account of the cultural practices surrounding a girl coming of age. In her introduction to the novel, Holmström draws attention to how the use of Tamil dialect in Bama's works reproduces the vernacular of women in her caste community, a language characterised by "vigour, and its closeness to proverbs, folk songs, and folklore" (xx): "She breaks the rules of written grammar and spelling throughout her 
work, elides words and joins them differently, demanding a new and different pattern of reading in Tamil" that is based on the everyday language used by "the women of her community" (xix). Both the language and chapter structure reflect orality and validate Dalit women's culture and traditions as worthy of preservation and communication.

Limbale's Hindu also refuses linear narrative. The novel is comprised of various plotlines that centre on the murder of Tatya Kamble, a Dalit activist and jalsa or street theatre performer killed in retribution for challenging the caste system and Hinduism. The narrative recounts the murderers' arrest, trial, and eventual acquittal. While the account of police and judiciary corruption is a familiar one in the Indian media, the novel complicates the narrative by focusing on Dalit figures who are convinced by upper-caste characters to betray the Dalit movement. The narrative structure is startlingly disorienting and fractured. Its fragmentation challenges the linearity of a conventional plot, and its polyphony lacks the orchestration of a clearly positioned narrator. Key events such as the murder are narrated more than once from different perspectives in order to destabilise the narrative and provide a complex account of characters' motivations and conflicting perceptions. These experimental features resemble postmodernist techniques, but whereas postmodernist aesthetics are often motivated by the intent to destabilise and challenge the very concept of truth or metanarratives, Hindu meticulously paints an intricate picture of India's political landscape in which the operation of power through hierarchies of caste, class, gender, and religion has an uncontested truth-content that is visible in the characters' daily lives. The narrative structure resembles a mosaic that gradually reveals a more complete image. When viewed as a whole it reveals the social totality and insists on the necessity of representing the truth no matter how much it is obscured by complex and shifting political allegiances and social divisions.

The novel's main point of view - that of an omniscient, unobtrusive, and detached third-person narrator-is frequently interpolated by longer passages focalised through the perspective of Sonali, the wife of Tatya Kamble's murderer, who witnesses Tatya's death from the rooftop of her house and is gradually ground down by her feelings of guilt and her love 
for Tatya's son Rohit. However, a first-person narrator, Milind Kamble (whose repulsive character and speech are distinctive), often interrupts the third-person narration. Milind Kamble is an unemployed Dalit "activist" who, like Sonali, witnesses Tatya Kamble's murder, fails to act to bring the killers to justice, and thereby becomes complicit in the crime. He consorts with upper-caste twins Manikchand and Gopichand, who manipulate the events following Tatya Kamble's murder to their own advantage. Milind Kamble systematically betrays his wife and the Dalit cause and wallows in self-loathing and rationalisation of his own complicity: "I should become a witness, make Tatya Kamble's murderers wear handcuffs. . . . But why did I feel so scared? . . . I was a parasitical plant attached to the movement. . . . People come to me with all sorts of requests, I do their work and take their money" (Limbale, Hindu 21). It is unusual to encounter such a self-consciously depraved Dalit narrator in Dalit literature, which is frequently populated by courageous or suffering protagonists. His satirical representation is a function of the text's internal critique, which is primarily aimed at a Dalit audience and intended to produce recognition of the corruption that weakens the Dalit movement and divides it against itself. The alternation between complex narrative perspectives asks the reader to assemble many disparate pieces of information into a disheartening picture of Dalit politics in Maharashtra at the turn of the millennium.

Hindu also draws on oral cultural forms in its representations of jalsa or Ambedkarite educational street theatre, a form of folk theatre used as a vehicle for Dalit activism by educating its Dalit audience. The jalsa performances in the novel, which are allegorical stories about the dangers of being seduced and betrayed by enemies of the Dalit movement, politicise the Mahar audience. The plays' plots critique the fracturing of Dalit politics and thereby echo and reinforce the novel's narrative. The novel, in turn, incorporates long passages of dialogue reminiscent of a didactic play. It mirrors the form and content of a modern jalsa performance, although one that does not recast myths and allegories but is resolutely committed to realism. ${ }^{7}$

Similar to Bama's and Limbale's novels, Kalyana Rao's Untouchable Spring does not follow a linear narrative structure. The novel narrates the 
history of a Dalit family and community over several generations, beginning at a point before the influence of colonisation in Coastal Andhra. It deploys a frame narrative, centred on the character of Ruth, which provides a fairly chronological account of Ruth's husband Reuben's family. However, the novel's large cast of significant characters, abrupt changes of narrative tone and style, and quick intercuts between frame narration and the main narrative produce a challenging experience for the reader. The narrative complexity is intensified by the tortuous manner in which the story of the Dalit family is passed from generation to generation. Reuben, who grows up in an orphanage, is only able to record his family's history after piecing it together from stories, songs, and the memories of people from his father's village: "They began to tell me and talk about our people. Then I came to know. That my grandfather, Yellanna[,] used to weave songs, sing them. . . . They sing all night. Couldn't find anyone who could sing it fully" (Kalyana Rao, Untouchable 179-80). He records his findings in a diary and Ruth bases the remaining story on anecdotes that Reuben collected. After Reuben's death, an elderly Ruth passes them on to the unnamed first-person narrator. This complex narrative structure criticises the linear narrative conventions of both novels and historical writing and demonstrates the insufficiency of individualist notions of memory to capture collective Dalit history. A global reader immersed in the cultural logic of postmodernism may be inclined to interpret these literary techniques as destabilising the narrative's truthtelling. However, the novel insists that by presenting a narrative as oral and passed down through generations, the story accumulates rather than diminishes in truth value. The novel represents its narrated history as an intricately woven tapestry composed by many people. Aesthetic features and formal structures that could be perceived as postmodernist are actually a product of the "radicalisation" of communal oral narrative strategies translated into novel form.

Like Hindu, Untouchable Spring incorporates oral narrative forms. It posits Dalit performative art forms such as the street theatre Veedhi Bagotam and Urumula dance as privileged sites of resistance. The narrative is frequently interrupted by footnotes that confront the lack of historical documentation of Dalit oral folk art in Indian scholarship. One 
such note criticises scholars who "have been unable to see the beginnings of Telugu drama in Veedhi Bagotam. There are many critical works on Telugu drama. . . . [T] here will not be any mention of veedhi nakatams, street plays.... The untouchable castes put on Veedhi Bagotams" (268). Untouchable Spring confidently represents Telugu Dalit dramatic and artistic traditions as highly developed and aesthetically sophisticated. Kalyana Rao insists that, in contrast to the artificiality of upper-caste art forms, Dalit art forms are "natural" and in touch with people's language and consciousness: "In fact, it is only in folk art that there is purity and integrity. There is frankness and naturalness. That's why it is still alive even though it has been thrown and cast away" (Untouchable 101). Dalit folk song is represented as "a village song" that was "born from every work done on this earth" (42). The novel depicts folk art, theatre, and dance as forms of revolt against the oppression of the Malas and Madigas and suggests that they are both an unconscious and conscious form of resistance:

Naganna [Reuben's ancestor] used to think his dance was only to worship Ganga. Only to please Siva, he thought. He was under the illusion that the roar of thunder that touched the heart and reverberated in nature was to bring down Ganga. His rhythmic beats and expression of emotion, all stopped there in the jataras. But every bit of the 'puranic secrets' that Chandrappa told him, the words that Naganna spoke whenever necessary, were only to say that he and his people were not any less. What was visible in him was revolt. He may not even be aware that it was revolt. But it was definitely revolt. (Untouchable 43)

In his influential work The Flaming Feet, Dalit critic D. R. Nagaraj argues for a reassessment of folk art as both a form of subaltern art and a resource for contemporary Dalit art and literature: "Folk epics . . . are necessarily the creation of subaltern communities [that] are never canonized in the history and theories of Indian literature" (190). Both Nagaraj and Kalyana Rao argue for a de-hierarchization of Indian literature that enables Dalit literature to find a legitimate space within Indian 
literature. Such a legitimation would also entail a recognition of the way Dalit fictions such as Sangati, Hindu, and Untouchable Spring incorporate innovative mixes of genres and traditional forms that challenge the aesthetics of mainstream literature. At the same time, however, the subaltern vernacular traditions and histories of caste resistance on which the novels draw are to some extent rerouted and radicalised in order to turn them into cultural resources that can be employed to re-envisage the world.

\section{The Political Imagination of a Dalit Future}

In his critical essays, Limbale argues for the necessity of Dalit literature's vision of a world free from caste discrimination (Towards an Aesthetic 37). The three novels I use as case studies gesture towards such a vision in different ways, and I will demonstrate how their experimental features are bound up with their attempts to imagine a world beyond untouchability and caste discrimination. Bama's Sangati explicitly performs an intersectional critique of both the caste system and patriarchy and represents Dalit women's resilience as an inspiration for the fight against discrimination. In this double critique of caste and patriarchy, the lines of solidarity and opposition constantly shift. The novel highlights the chasm between Dalit women and upper-caste women who exploit and humiliate them as well as the gendered fault lines of the Dalit community. The text condemns and explains the often brutal behaviour of Dalit men towards the women of their caste community: the caste system humiliates Dalit men so persistently that the people against whom they lash out are usually their wives, daughters, and female relatives. On the other hand, the text emphasises that caste produces a strong bond between the men and women of a Dalit community while also gesturing at the gendered community of women as a whole. Although the text is primarily an intimate portrayal of a community of Christian Dalit women and concerned with female Dalit empowerment, it signals the necessity of female solidarity beyond caste boundaries as well as the unity of the Dalit community as a whole to fight caste discrimination. Despite Sangati's polemical critique of caste and gender discrimination, the idea of inclusion is built into the novel's form and content. The fluidity of the 
narrative structure lends itself to a flexible sense of community and the notion of belonging to multiple communities. Sangati's porous narrative structure therefore works towards overcoming a fractured caste system, community, and society and deploys experimental aesthetics to envision an inclusive world.

Unlike Bama's Sangati, in which the operative totality of the Dalit community is prioritised over that of the nation-state, Limbale's Hindu engages with the notion of the nation as fractured along caste lines. In his preface, "Straight from the Heart," Limbale proposes that only a casteless nation can be a unified nation:

The fabric of Hindu society, interwoven with inequality, and the disfigurement of the caste system-Hindu has been written to perform a post-mortem of these two. Our country cannot become beautiful until the stain of the caste system is washed away from its face. To speak against the caste system is to speak the language of national unity, of aesthetic beauty. (xii)

Limbale aligns the notion of the aesthetic sublime with an image of a casteless nation, but his novel offers only partial hope of this vision's realisation. Hindu portrays a powerful Dalit movement that resists caste and is, to some extent, inclusive of other oppressed castes and communities. As such, the movement's imagined inclusiveness offers a potential blueprint for a just nation, but the narrative is overwhelmingly characterised by crisis and fragmentation. Rather than project a vision of a better future, the novel provides a negative critique of the national status quo and concludes with a scene in which the first-person Dalit narrator submissively takes the hand of one of the manipulative upper-caste twins, "kissing it loyally" (Limbale, Hindu 155). It is significant, however, that most narrative sympathy is invested in Sonali, who is tragically trapped in pernicious power structures in which only the ruthless and corrupt thrive. The novel's uncompromising insistence on providing a nuanced and complete picture of the contemporary moment implies a desire for a world that would enable the creation of a more coherent and uplifting narrative. The novel's fragmentation and structural complexity, which mirror the disunity of a Dalit movement fractured by social hier- 
archies, critique the contemporary reality whose negativity is the inverse of that which the novel seeks to invoke.

By contrast, Kalyana Rao's Untouchable Spring is more epic in scope and utopian in conception. It functions less as a negative critique than a poetic celebration of Dalits as individuals and as a community and insists that their dignity, wealth of artistic talent, and beauty are the creative seeds of an equal, flourishing, and just society. The novel's conclusion depicts the youngest members of the family putting their hope in the Naxalite struggle, a form of resistance outside the realm of what the Indian state considers a legitimate form of protest. As such, the text announces the need for radical Marxist-inspired change that addresses caste and class inequality. On the level of form, this conclusion invokes an irrepressible movement towards a better, more equal, and just world even though, paradoxically, the novel's complex narration relentlessly undermines any form of historical positivism or linear development. ${ }^{8}$ Indeed, the epigraph in the preface demonstrates the necessity of rejecting the notion of untouchability as timeless and resisting the logic of historical chronology:

This Spring was forbidden then.

Now, too, forbidden.

The caste of birth forbidden.

The chosen struggle forbidden.

It may have been yesterday. Maybe today.

Maybe any time.

This Spring was forbidden then.

Now, too, forbidden. (vii)

Similarly, the tortuous way in which the family's history is passed on through generations suggests that their story and that of the "Untouchable Spring" cannot be repressed despite seemingly insurmountable obstacles. The novel teaches that sacrifice has always been needed in the attempt to create a world free of caste, gender, and class discrimination, but it also insists that sacrifice is never in vain. Inspirational stories of 
individual characters' courage and sacrifice are repeated again and again. The complex narrative temporality endeavours to preserve the past or continuity with the past, as well as conceive a future that has not yet come into being but is immanent in the present, even if it is frequently forestalled.

\section{Positioning Readers of Dalit Fiction: Local, National, and Global Audiences}

Dalit literature's experimental features and inclusive vision of the future are inextricably intertwined with the complex ways in which it addresses several audiences at once. Three distinct kinds of readers are addressed in Dalit writing: Dalit readers, non-Dalit Indian readers, and global consumers. The subcontinental readership, both Dalit and non-Dalit, is usually the focus of Dalit criticism. Limbale, for example, emphasises the mode of dual address in Dalit literature: "The form of Dalit literature is inherent in Dalitness, and its purpose is obvious: to inform Dalit society of its slavery, and narrate its pain and suffering to upper caste Hindus" (19). In his introduction to Poisoned Bread, his groundbreaking anthology of Marathi Dalit writing in English translation, Arjun Dangle extends the pedagogical reach of Dalit texts to include an international readership: "Dalit literature is one which acquaints people with the caste system and untouchability in India, its appalling nature and its system of exploitation" (lii). K. Satyanarayana and Susie Tharu, in their introduction to their collection of English translations of Dalit writing from Tamil Nadu and Kerala, argue that these translated texts have a dual function, one for Dalits and one for the rest, since they "will make dalit life not just visible, but also meaningful, accountable to dalits and ethically compelling for everyone" (Introduction, No Alphabet 55). Dalit critic Aniket Jaaware, however, problematizes the pedagogical function of Dalit literature for its non-Dalit subcontinental consumers:

The circulation and consumption of dalit poetry can be encapsulated as follows: the non-dalits managed to eat the dalit, without ever really having to eat with the dalit. The only metonymy through which the non-dalits can bear the touch of the dalit is 
through the dalit's words. It would be so very difficult to touch the real body of a real dalit, or to eat with him, in the same plate, or to allow our daughter to marry a dalit. (281; emphasis in original)

The moment a Dalit text is circulated as a commodity, authors lose control over how the texts are read and used. The three Dalit texts I discuss respond to this uncertainty over reception and autonomy by trying to "touch" their readers and engage them closely, but their address is modulated according to audience.

All three novels are explicit in their direct address of specific, regional Dalit audiences. Their validation of the Dalit experience and critique of upper-caste behaviour is read by many Dalit critics as motivated by a desire to instil a combative "Dalit consciousness" in Dalit readers (Brueck 10-15). Kalyana Rao's novel does this most overtly when it represents Dalit resistance to oppression and Dalit art as part of a long and proud history. Limbale's novel is mainly an exercise in self-critique of the Dalit movement and therefore explicitly addresses that audience. Bama's novel primarily addresses a female Dalit audience and critiques the Dalit community's patriarchal structures but also celebrates Dalit folk art and Dalit women's unique culture. In the translated acknowledgements section of the 1994 Tamil edition of Sangati, Bama claims that "Sangati grew out of the hope that the Dalit women who read it will rise up with fervour and walk towards victory as they begin their struggle as pioneers of a new society" (iix). The three texts' experimental and innovative form interpellates the Dalit reader as a sophisticated reader who will embrace the task of engaging with such complex works.

Similarly, all three texts expose caste prejudice and discrimination perpetrated by upper castes and, like all Dalit literature, offer a scathing critique of such practices. The target of such critique is clearly a wider national or subcontinental audience outside the Dalit community, even if this readership is more implicitly invoked. None of the texts addres an upper-caste audience as explicitly as Baby Kamble in her autobiogra phy The Prisons We Broke. She asks: "Your palaces are built with the soil soaked with the sweat and blood of Mahars. But does it rot your skin? 
You drink their blood and sleep comfortably on the bed of their misery. Doesn't it pollute you then?" (56). However, all three novels imply such an address by listing horrific instances of caste oppression such as the lynching of Tatya Tamble in Hindu, the Dalit women's constant fear of being harassed and raped by upper-caste men in Sangati, and the frequent murders and relentless persecution of Dalits in Untouchable Spring. In Kalyana Rao's novel the massacre of Dalits is represented in a way that signals both the condemnation of caste violence and the Dalit voice's insistence on being heard:

The deadly massacre that appears in front of Ruth's eyes. . . . The upper castes chasing the malas and madigas with spears and crowbars. The helpless running away in frenzy and in fear. Their cries of agony. ...

A scene.

A scene that can never be erased.

A scene drawn with blood. (176)

The repetition of sentence fragments summons the reader and holds her back, compelling her to fully visualize the scene and examine her own responsibility for preventing caste violence in contemporary India.

The third readership, a global audience unmarked by caste, is inscribed less explicitly in Dalit literature. This readership is welcome because the texts assume solidarity with the destitute worldwide and anyone resisting oppression is invited to be an ally. However, all three novels were published at a time when Dalit literature was largely ignored outside of India and published mainly by small presses, often without access to translation. As a result, the authors could not anticipate that a global audience would be willing to listen to their stories. Even in their later English translations, the texts are chiefly addressed to a transregional Indian audience; for example, Mukherjee's introduction to Hindu is explicitly addressed to "Indian readers" (xxvii). The novels make few concessions to a global audience and rarely offer explanations of specific regional customs and history. Kalyana Rao and the translators of Untouchable Spring provide footnotes to help readers unfamiliar with the history of the region, Dalit culture, and the caste structure 
orient themselves, but the notes are just as necessary for a wider Indian audience. Hindu implicitly includes a non-Indian reader by drawing on the language of "human rights" that is addressed (at least in principle) to humanity as a whole (Limbale, Hindu 95). However, even though the discourse of human rights in Dalit writing can potentially redefine "caste as a universal form of discrimination" that participates in a "global struggle" (Satyanarayana 302, 292), the nation in Hindu remains the privileged site of reference for the Dalit movement.

The Dalit feminist stance of Bama's text is addressed to women in general. At various points in the novel, female characters and the female narrator see themselves as part of a community of women and assert a sense of solidarity with this global gendered community. Although they often experience discrimination at the hands of upper-caste women, they still feel a sense of allegiance to them and feel sorry that uppercaste women's lives are in some ways even more constrained than their own. Sangati may focus only on the small world of these Dalit women but it asserts their confidence in imagining the world outside of their village. The narrator's grandmother exemplifies this mindset even if her seeming lack of fighting spirit exasperates her educated feminist granddaughter:

'Whether it is right or wrong, it is better for women not to open their mouths. You just try speaking out about what you believe is right. You'll only get kicked and beaten and trampled on for your pains. And it isn't just here that it happens, you know. It's the same throughout the world. Women are not given that kind of respect.' Paatti scraped up the betel leaves and nut that she had crushed in her mortar, popped the mixture into her mouth, gave it a couple of good chomps, and stowed it away in her cheek.

'Look how she talks - as if she's been around the whole world,' I thought to myself. (Bama, Sangati 29)

This exchange at the beginning of the text demonstrates the ease with which the Dalit women see themselves as part of a gendered global community, even though upper-caste women "treat [them] with contempt, 
as if [they] are creatures of a different species" (66). Sangati records the women's seemingly submissive acceptance of the status quo but undercuts it by celebrating individual female characters' resistance, strength, and resilience. Raakamma, in an example of outrageous resistance, exposes her genitals in the street to shame her abusive husband into leaving her alone in order to avoid provoking even more scandalous behaviour on her part. In Bama's preface to the English edition of Sangati, she presents the characters as an example to all women in their "courage to break the shackles of authority, ... to roar" (vii).

If Sangati addresses a transnational feminist audience, Untouchable Spring similarly opens a dialogue with an internationalist audience through its Marxist and Naxalite vision of a better world. The novel represents the relationship between reclaiming the Dalit past and a revolutionary impetus as smooth, seamless, and self-evident. In the final pages, at the end of the twentieth century, Ruth writes a letter to her grandson, Jessie, who has joined the Naxalite struggle: "You're dreaming of a new man. You're dreaming of a new world. All those who are fighting in all countries at all times will be dreaming for that historic truth. All those dreams make up the book of revolution" (Kalyana Rao 263). However, the historical relationship between Marxism and Ambedkarism is fraught with the tensions of Indian Marxism's failure adequately to engage with the specificity of caste as opposed to class oppression (Limbale, Towards an Aesthetic 60-68).

Unlike the Dalit and subcontinental non-Dalit readers, the global reader is not assigned a clearly defined role in relation to the struggle against untouchability. Whereas, broadly speaking, the Dalit reader is supposed to be inspired and politicised and the Indian non-Dalit reader is encouraged to participate in the Ambedkarite struggle of annihilating caste, ${ }^{9}$ the global reader's role is hardly demarcated in the literary texts or Dalit criticism. Perhaps these novels can be read as interpellating this reader, who is unmarked by caste, as a witness, analogous to how the reader of Dalit autobiographies is conceptualised as "witness" (Nayar 91). Critics often interpret Dalit autobiographies as a form of testimonio, a "narrative of witnessing [that] enlists the reader as witness to this trauma" (Nayar 91). If this concept is extended to in- 
clude Dalit literature, the global reader can be perceived as being taken to task, even though the ethical implications of this form of address are far from clear.

\section{Translation as Experimentation}

The issue of translation-both linguistic and formal-further complicates the question of reader address. Translating a Dalit text into another language necessarily involves a re-coding of the text for a different audience and different market expectations. As I argue above, Dalit criticism often represents Dalit literature's experimental features as techniques that primarily serve a political purpose rather than as aesthetic strategies that need to be analysed for their own sake. However, the back cover blurbs of the three texts' English translations foreground the novels' experimental and innovative features. For instance, Sangatis blurb emphasizes the novel's polyphonic structure: "Flouting received notions of what a novel should be, Bama weaves many narratives together to explore social inequities—compounded[,] above all, by poverty—suffered by Dalit women." Hindu's back cover blurb markets its complex narrative perspective by drawing attention to the fact that " $[\mathrm{t}]$ he text switches from the first person narrative of a Dalit" to that of an unmarked thirdperson narrator. Mukherjee goes to great lengths in her introduction to Hindu to explain and almost defend the aesthetic value and narrative effectiveness of these experimental features that shatter "many of the taken-for-granted expectations that the universalized bourgeois reader has from this literary genre" (xvi). The blurb on Untouchable Spring advertises the text's challenge to genre boundaries by presenting it as "a memory text, ... a family/community saga, a novel and a historical document rolled into one" that "provides a historiography of the deprived." The reasons for considering these texts important and worthy of being studied and translated differ according to the way in which their experimental nature is perceived and valued. The translators' and editors' celebration of the texts' experimental features changes the way the texts are read. The texts are marketed to a global readership based mainly on their unconventional narrative techniques as well as their ability to provide insight into subaltern lives. 
While the three English translations re-code the texts for international consumption, they also try to preserve the novels' estrangement effects. In their attempts to replicate the Dalit novels' innovative features, the translations are emphatically experimental. A defining characteristic of Dalit literature in English translation is the high visibility of the translator, who usually problematises her position as upper caste. All novels include a lengthy introduction by the translator that contextualises the text culturally and historically, analyses it, and discusses challenges of and strategies for translating it. ${ }^{10}$ The sheer visibility of the translator and the process of translation adds a degree of self-reflexivity to the translated work, which can itself be considered experimental.

The translators directly address the specific challenges of translating Dalit literature and its language. Holmström, for example, draws attention to Bama's radical challenge to Tamil literary language by employing colloquial and other non-literary language: "If [Tamil Dalit writing] brings into Tamil literature subject matter hitherto considered inappropriate, it uses a language hitherto considered unprintable" (xiii). This untranslatable "unprintability" is transformed into a different kind of strangeness in the English translation by using Tamil words such as Paatti (grandmother) and names for food and garments that could quite easily be translated. One aspect of Bama's use of non-literary language is the inclusion of profanity the women use as a matter of course. This feature of Bama's use of Tamil is almost untranslatable into English since it is difficult, if not impossible, to translate the shock factor of Dalit literary language to an English-speaking audience. The passages that include profanity appear directly translated, look "foreign" rather than shocking, and remind readers that they may have only limited insight into the text and its culture of origin. Raakkamma, for example, abuses her brutal husband: "Disgusting man, only fit to drink a woman's farts! . . Why don't you drink my monthly blood?” (Bama, Sangati 61). The introductory sentence of the novel's final chapter also appears to be a literal translation and reminds the reader of the text's "foreignness": "The rain was pissing down as if an elephant was up there in the sky" (111). The presence of a glossary in Sangati implies that the translated words inadequately capture their meaning 
and draws attention to the fact that some words and concepts resist translation.

Hindu, a text primarily addressed to an Indian audience, does not contain a glossary and, compared to the other two novels, includes the fewest in-text explanations. A phrase such as "dal roti" (Limbale 82), which refers to the basic meal of lentils and bread, remains untranslated and unexplained (the phrase "daily bread," for example, could have been substituted for "dal roti" for easier consumption by a non-Indian reader). Instead of footnotes or a glossary, Mukherjee provides a detailed introduction in which she acknowledges the significance of full names in the novel:

One of the most striking aspects of Limbale's narration is the use of the full names of characters. . . Hindu has made me realize that the mainstream novel, whether in India or abroad, creates a false universality and a fake intimacy by putting the reader on a first name basis with its characters, subtly implying that the caste, race or religion of the characters do not matter. A dalit writer who is fighting against caste oppression cannot and does not want to create this false intimacy as his very subject matter is the fractures in the human community along caste lines. (xxi)

However, rather than explaining the significance of the names in detail, the reader is only made aware of the names' importance. Ultimately, like the translator, the reader must figure out the distinct caste hierarchy in Achalpur, Tatya Kamble's village: "Although as a Punjabi, I did not instantly recognize the denotations of the caste names as savarnas [upper-castes characters] or avarnas [Dalits], or their internal hierarchies, a careful second reading of the novel educated me to the caste divisions in Achalpur" (Mukherjee xxii).

Among the three novels, the translation of Untouchable Spring foregrounds its status as a translated text in the most radical way. Translators Uma and Sridhar employ ungrammatical, incomplete, and fragmented syntax and an often aggressive, clipped language. This is clearly a deliberate choice since a different translation of an extract of Untouchable 
Spring by R. Akhileshwari uses distinctly different strategies that make the novel sound less "strange." Uma and Sridhar's translation reads: "He narrated how a memory blossomed at every turn and withered away. Told stories. Wove poems. Causing an upsurge he left, asking her to keep this memory in her heart. In truth, it is not a memory. A surge. How to contain that flow!" (1). The same moment in Akjileshwari's translation reads:

A memory sprouted at every turn; a memory blossomed in every corner. It seemed as if the fallen blossoms-memories of Reuben-had carpeted the ground, her life! It seemed as if Reuben had strung the blossoms into garlands, and created poetry! These were the blossoms that had actually churned the depth of her being. They were not mere memories. They were a torrent. Now, how is one to control a torrent? (472)

In contrast to Akhileshwari's more elaborate sentence structures and use of "flowery" language, Uma and Sridhar use sentence fragments and strip down the text's language, making it direct, condensed, and unadorned. One cannot read Uma and Sridhar's translation and not be constantly reminded that one is reading a translated text. This radical form of translation goes against all the rules of conventional translation practice since the text presents itself emphatically as a translated text that interrupts a smooth reading process rather than making the translation process invisible. Usually the re-coding of a Dalit text in translation for a global audience involves drawing attention to the text's experimentation with form rather than language, but Uma and Sridhar's translation tries to capture Kalyana Rao's experimentation with literary language in innovative but possibly controversial ways. Kalyana Rao's text is renowned for its lyrical quality in Telugu, and the English translation stresses its aggressive and revolutionary stance by fracturing syntax and introducing a staccato rhythm; in other words, the translators may have opted to violate English grammar in order to enhance the novel's radical message in translation. All three translations resist the smooth incorporation of Dalit literature in the global marketplace as an easily consumable commodity by employing experimental translation techniques and unwieldy 
apparatuses such as footnotes, glossaries, and long explanatory translator's comments that put their readers to task. The translations are most faithful to the original texts in their resistance to the easy consumption of the Dalit.

\section{Conclusion}

While Dalit literature is often read within a mode of criticism that focuses on the social and political content of the texts, I argue that is possible to read the form and aesthetics of Dalit fiction as a corollary of their politics rather than a diminution of them. Furthermore, I contend that a transregional comparison of translations of Dalit literature that is attentive to their local specificities as well as their commonalities of form and mediation for global markets has much to offer to postcolonial studies and world literary studies. Part of this contribution is a much better understanding of how the changing realities of caste and resistance to caste shape subaltern writing and experience in the subcontinent. Ambedkar famously maintained that caste needed to be annihilated in independent India. Although this belief is still prevalent, Dalit organisations increasingly argue for the need to reconceptualise caste in a way that will eradicate caste discrimination but not the distinct cultural identity of sub-castes such as the Madigas in South India: "In the new discourse, caste is reshaped into a social collectivity in which related castes engage in a horizontal political grouping [with the aim of] reformulating democracy" (Satyanarayana and Tharu, Introduction, No Alphabet 64-65). All three texts participate in this changing discourse. Their experimental features gesture at such a reconfiguration of caste and community to imagine a better world. In their various forms of tripartite address or intersectional critique of gender, caste, and class hierarchies, the texts evoke a horizon that extends beyond the local or the nation. Given that, the radical experimentation with form in Bama's Sangati, Limbale's Hindu, and Kalyana Rao's Untouchable Spring is directly related to the novels' attempts to represent different and new ways of imagining Dalit communities and their place in the world. Dalit literature is deeply rooted in specific locations, distinct vernacular oral literary traditions, and particular caste histories and cultures, and the three novels I explore invoke 
these oral traditions and cultural formations in complex narrative forms that combine fragmented and polyphonic narration, non-linear temporality, and a mixture of genres and local forms that resist linear history or narratives of individual development in favour of more interdependent articulations of community. Dalit literature employs an experimental aesthetic in the attempt to convey the distinct realities and radical politics of Dalits to multiple audiences in a globalising world. Considering the emergent global market for Dalit literature, English translations of Dalit literature are confronted by particular challenges relating to the texts' stylistic and narrative innovations. In responding to the language of Dalit texts as well as their cultural specificity, translations generate their own modes of self-reflexive experiment, which add a new formal layer of complexity to the texts and complicate the way the novels and their translations position and address Dalit and non-Dalit, Indian and international readers.

\section{Acknowledgements}

I would like to thank the AHRC for funding the research network "Writing, Analysing, Translating Dalit Literature" and Judith MisrahiBarak for making this research network possible. The network is hosted by the Centre for Postcolonial Studies at Nottingham Trent University in partnership with the EMMA research centre at the Université PaulValéry Montpellier. This essay benefitted greatly from the events and discussions that the network organised. I also thank the anonymous reviewers and special issue editors Sharae Deckard and Wendy Knepper for their valuable comments and suggestions.

\section{Notes}

1 The term "Dalit" means "ground down" and "broken to pieces" in Marathi and is a nom de guerre that Dalits adopted in the twentieth century. See Rao.

2 For a discussion of broader definitions of the concept of Dalit literature that include the work of other marginalised Indian communities and an analysis of the notion of Dalit consciousness, see Brueck 9-11 and 61-76. For a postcolonial analysis of caste, see Ganguly.

3 For a study of the autobiographical field of Dalit literature in Hindi, see Hunt. 
4 The original Marathi version, Dalit Sahityache Saundaryashastra, was published in 1996 by Kamble and Prakashan. The English version of the volume was translated by Alok Mukherjee.

5 See also the Dalit Panthers' Manifesto, reprinted in Satyanarayana and Tharu's The Exercise of Freedom.

6 For an introduction to Ambedkar, see Zelliot.

7 On the concept of "Dalit realism," see Gajarawala 16-23.

8 For an analysis of Dalit literature's interrogation of historicity, see Gajarawala 167-96.

9 See Ambedkar's Annihilation of Caste. It should be noted, though, that with the growth of Dalit sub-caste movements that assert the identity of specific castes, which began in the 1990s, "[c]aste annihilation . . . has to be rethought as a project where caste identities may remain as markers of a culture and history, but inequalities and indignities will be eliminated" (Satyanarayana and Tharu, Introduction, Steel Nibs 48).

10 For a discussion of specific challenges of translating Dalit writing into English, see Mukherjee, Mukherjee, and Godard.

\section{Works Cited}

Ambedkar, B. R. Annihilation of Caste. Ed. S. Anand. New Delhi: Navayana, 2014. Print.

Bama. Acknowledgements. Sangati. Trans. Lakshmi Holmström. 1994. New Delhi: Oxford UP, 2005. ix-x. Print.

—. Karukku. Trans. Lakshmi Holmström. New Delhi: Oxford UP, 2011. Print.

—. Preface. Sangati. Trans. Lakshmi Holmström. New Delhi: Oxford UP, 2005. vii-viii. Print.

—. Sangati. Trans. Lakshmi Holmström. New Delhi: Oxford UP, 2005. Print.

—. Vanmam. [Vendetta]. Trans. Malini Seshadri. New Delhi: Oxford UP. Print.

Bray, Joe, Alison Gibbons, and Brian McHale. Introduction. The Routledge Companion to Experimental Literature. Ed. Bray, Gibbons, and McHale. London: Routledge, 2012. 1-18. Print.

Brueck, Laura R. Writing Resistance: The Rhetorical Imagination of Hindi Dalit Literature. New York: Columbia UP, 2014. Print.

Dalit Panthers' Manifesto. 1973. The Exercise of Freedom: An Introduction to Dalit Writing. Ed. K. Satyanarayana and Susie Tharu. New Delhi: Navayana, 2013. 55-64. Print.

Dangle, Arjun. "Introduction: Dalit Literature Past, Present and Future." Poisoned Bread: Translations from Modern Marathi Dalit Literature. Ed. Dangle. Hyderabad: Orient Blackswan, 2009. ixx-liv. Print.

Gajarawala, Toral Jatin. Untouchable Fictions: Literary Realism and the Crisis of Caste. New York: Fordham UP, 2013. Print. 
Ganguly, Debjani. Caste, Colonialism and Counter-Modernity: Notes on a Postcolonial Hermeneutics of Caste. London: Routledge, 2005. Print.

Holmström, Lakshmi. Introduction. Sangati. By Bama. New Delhi: Oxford UP, 2005. xi-xxiii. Print.

Hunt, Sarah Beth. Hindi Dalit Literature and the Politics of Representation. New Delhi: Routledge, 2014. Print.

Jaaware, Aniket. "Eating, and Eating with, the Dalit: A Re-Consideration Touching upon Marathi Poetry." Indian Poetry: Modernism and After. Ed. K. Satchidanandan. New Delhi: Sahitya Akademi, 2001. 262-93. Print.

Kalyana Rao, G. Untouchable Spring. Trans. Alladi Uma and M. Sridhar. Hyderabad: Orient Black Swan, 2010. Print.

—_. "Untouchable Spring: Excerpts." Trans. R. Akhileshwari. Steel Nibs Are Sprouting: New Dalit Writing from South India. Dossier II: Kannada and Telugu. Ed. K. Satyanarayana and Susie Tharu. Noida: Harper, 2013. 472-94. Print.

Kamble, Baby. The Prisons We Broke. Trans. Maya Pandit. Hyderabad: Orient Blackswan, 2009. Print.

Limbale, Sharankumar. Hindu. Trans. Arun Prabha Mukherjee. Kolkata: Samya, 2010. Print.

—. "Straight from the Heart." Preface. Hindu. Trans. Arun Prabha Mukherjee. Kolkata: Samya, 2010. ix-xii. Print.

—. Towards an Aesthetic of Dalit Literature: History, Controversies and Considerations. Trans. Alok Mukherjee. Hyderabad: Orient Longman, 2004. Print.

Mukherjee, Arun Prabha. Introduction. Hindu. By S. Limbale. Kolkata: Samya, 2010. xiii-xxix. Print.

Mukherjee, Arun Prabha, Alok Mukherjee, and Barbara Godard. "Translating Minoritized Cultures: Issues of Caste, Class and Gender." Postcolonial Text 2.3 (2006): 1-23. Print.

Nagaraj, D. R. The Flaming Feet and Other Essays: The Dalit Movement in India. Ed. Prithvi Datta Chandra Shobhi. London: Seagull, 2011. Print.

Nayar, Pramod K. "Bama's Karukku: Dalit Autobiography as Testimonio." Journal of Commonwealth Literature 41.2 (2006): 83-100. Print.

Omvedt, Gail. "Literature of Revolt: Prefatory Note." Poisoned Bread: Translations from Modern Marathi Dalit Literature. Ed. Arjun Dangle. Hyderabad: Orient Blackswan, 2009. ix-xviii. Print.

Rao, Anupama. "Who Is the Dalit? The Emergence of a New Political Subject." Claiming Power from Below: Dalits and the Subaltern Question in India. Ed. Manu Bhagavan and Anne Feldhaus. New Delhi: Oxford UP, 2008. 11-27. Print.

Ravikumar. General Introduction. The Oxford India Anthology of Tamil Dalit Writing. Ed. Ravikumar and R. Azhagarasan. New Delhi: Oxford UP, 2012. xivxxxiii. Print. 
Reddy, N. Manohar. "Inventing a Dalit Aesthetic." 50 Writers, 50 Books: The Best of Indian Fiction. Ed. Pradeep Sebastian and Chandra Siddan. Noida: HarperCollins, 2013. 86-91. Print.

Satyanarayana, K. "Caste as the Baggage of the Past: Global Modernity and the Cosmopolitan Dalit Identity." Dalit Literatures in India. Ed. J. K. Abraham and J. Misrahi-Barak. London: Routledge, 2015. 289-306. Print.

Satyanarayana, K., and Susie Tharu, eds. The Exercise of Freedom: An Introduction to Dalit Writing. New Delhi: Navayana, 2013. Print.

—. Introduction. No Alphabet in Sight: New Dalit Writing from South India. Dossier I: Tamil and Malayalam. Ed. Satyanarayana and Tharu. New Delhi: Penguin, 2011. 1-69. Print.

- Introduction. Steel Nibs Are Sprouting: New Dalit Writing from South India. Dossier II: Kannada and Telugu. Ed. Satyanarayana and Tharu. Noida: Harper, 2013. 1-54. Print.

Zelliot, Eleanor. Ambedkar's World: The Making of the Babasaheb and the Dalit Movement. New Delhi: Navayana, 2013. Print. 